\title{
Duchowni prawnie uznanych wyznań jako świadkowie w postępowaniu podatkowym
}

\section{Priests of legally confirmed beliefs as witnesses in tax proceedings}

Streszczenie. Przedmiotem artykułu są zagadnienia związane z wykorzystaniem przez organy administracji publicznej w jurysdykcyjnym postępowaniu podatkowym środka dowodowego z przesłuchania osoby duchownej jako świadka. Autor podkreśla, że zgodnie z art. 195 pkt 3 Ordynacji podatkowej świadkami nie mogą być duchowni prawnie uznanych wyznań co do faktów objętych tajemnicą spowiedzi, jednakże już inne wiadomości pozyskane przez duchownego - w ramach szeroko rozumianej „opieki duchowej” - nie mieszczą się w powyższym bezwzględnym zakazie dowodowym. Stąd też autor zgłasza postulat de lege ferenda, aby wprowadzić do art. 195 pkt 3 o.p., wzorem m.in. Ordynacji podatkowej z 1934 r., tzw. tajemnicę duchowną/duszpasterską, która dotyczyłaby wszystkich wiadomości/informacji uzyskanych przez osoby duchowne prawnie uznanych wyznań przy wykonywaniu swoich „funkcji duszpasterskich”, a nie stricte związanych z instytucją spowiedzi. 
Słowa kluczowe: duchowny; postępowanie podatkowe; spowiedź; organ podatkowy; świadek; procedura podatkowa.

\begin{abstract}
The subject-matter of the paper involves issues related to the use of evidence from hearing a priest as a witness in jurisdiction tax proceedings by public administration bodies. The author emphasizes that pursuant to Article 193 point 3 of the Tax Ordinance Act priests of legally confirmed religions may not witness on facts that are subject to the seal of confession. However, other information obtained by the priest - under the broadly understood "spiritual care" is not subject to the above absolute evidentiary prohibition. This is why the author brings in a de lege ferenda postulate to introduce to Article 195 point 3 of the Tax Ordinance Act, as modelled on i.a. the 1934 Tax Ordinance Act, the so-called "spiritual/pastoral confidentiality" which would relate to all information obtained by the clergy of legally confirmed beliefs from a faithful when performing their "pastoral functions", but not stricte related to confession only.
\end{abstract}

Keywords: priest; witness; confession; tax proceedings; tax authority; tax procedure.

\title{
1. Uwagi wprowadzające
}

Status duchownych prawnie uznanych wyznań jako świadków na gruncie jurysdykcyjnego postępowania podatkowego rzadko bywa przedmiotem publikacji naukowych, a szkoda, ponieważ instytucja, która prima facie wydaje się jasna, w praktyce wywołuje liczne wątpliwości interpretacyjne. Tym samym, z przyczyn oczywistych jednym z celów niniejszego opracowania jest wypełnienie tejże luki w piśmiennictwie. Aby jednak prawidłowo „odkodować” obszar badawczy zakreślony tytułem artykułu, należy w pierwszej kolejności ustalić pozycję prawną kościołów i związków wyznaniowych w prawie powszechnie obowiązującym na terytorium Rzeczypospolitej Polskiej wraz ze statusem osób duchownych, ponieważ ustawodawca, nie definiując pojęć „duchowny/osoba duchowna”1, pozo-

1 Por. S. Babiarz, S. Bogucki, A. Dumas, R. Pęk, S. Presnarowicz, J. Pustuł, Ryczałty w prawie podatkowym, LEX/el. 2012; P. Borszowski, Ustawa o zryczałtowanym podatku dochodowym od niektórych przychodów osiqganych przez osoby fizyczne. Komentarz, LEX/el. 2012. 
stawił nolens volens wypełnienie tejże luki doktrynie oraz judykaturze ${ }^{2}$. Zasadnicza jednak część opracowania poświęcona została środkowi dowodowemu z przesłuchania osoby duchownej jako świadka oraz bezwzględnemu zakazowi dowodowemu unormowanemu $\mathrm{w}$ przepisie art. 195 pkt 3 Ordynacji podatkowej ${ }^{3}$ wraz ze zgłoszonymi postulatami de lege ferenda w zakresie „tajemnicy duchownej (duszpasterskiej)”.

Teza badawcza zmierza do udzielenia odpowiedzi na podstawowe pytanie: jakie powinny być dopuszczalne granice korzystania z zeznań osoby duchownej prawnie uznanego wyznania jako świadka.

\section{Kościoły i związki wyznaniowe}

W świetle art. 25 ust. 1-3 Konstytucji Rzeczypospolitej Polskiej ${ }^{4}$ kościoły i inne związki wyznaniowe są równouprawnione, a stosunki między państwem polskim a tymi ostatnimi podmiotami są kształtowane na zasadach poszanowania ich autonomii oraz wzajemnej niezależności każdego w swoim zakresie, jak również współdziałania dla dobra człowieka i dobra wspólnego ${ }^{5}$. Jeśli chodzi o stosunki pomiędzy Rzecząpospolitą Polską a Kościołem Katolickim jako największą wspólnotą wyznaniową w Polsce $^{6}$, reguluje je umowa międzynarodowa zawarta ze Stolicą Apostolską, tzw. Konkordat podpisany w dniu 28 lipca 1993 r. i ratyfikowany 23 lute-

2 Por. P. Dańczak, Inni uczestnicy postępowania administracyjnego [w:] W. Chróścielewski (red.), Zakres przedmiotowy i podmiotowy postępowania administracyjnego ogólnego, tom II, część 1 [w serii:] G. Łaszczyca, A. Matan (red.), System Prawa Administracyjnego Procesowego, Warszawa 2018, s. 523; M. Jurzyk, Ochrona spowiedzi w postępowaniu dowodowym a prawa penitenta i duchownego, „Radca Prawny” 2004, s. 67; B. Pieron, Równe czy identyczne traktowanie osób duchownych w prawie polskim? „Annales Canonici” 2017, nr 13, s. 156 i n.

3 Ustawa z dnia 29 sierpnia 1997 r. Ordynacja podatkowa (tekst jedn. Dz.U. z 2020 r., poz. 1325 ze zm.), dalej: o.p.

4 Ustawa z dnia 2 kwietnia 1997 r. Konstytucja Rzeczypospolitej Polskiej (Dz.U. z 1997 r., Nr 78, poz. 483 ze zm.), dalej: Konstytucja RP.

5 Zob. także I. Nowak, Wolność jednostki w zakresie przekonań religijnych i światopoglądowych a zwolnienie od pracy i nauki z tytułu święta religijnego - soboty (szabatu, szabasu), „Przegląd Prawa Publicznego” 2013, nr 1, s. 20-21.

6 W 2019 r. Kościół Rzymskokatolicki (obrządek łaciński) liczył 32.460.984 ochrzczonych wyznawców - D. Rozkrut (red.), Mały Rocznik Statystyczny Polski, Warszawa 2020, s. 118. 
go 1998 r. ${ }^{7}$, oraz ustawa z dnia 17 maja 1989 r. o stosunku Państwa do Kościoła Katolickiego w Rzeczypospolitej Polskiej ${ }^{8}$. Natomiast stosunki pomiędzy Rzecząpospolitą Polską a innymi kościołami oraz związkami wyznaniowymi normują ustawy uchwalone na podstawie umów zawartych przez Radę Ministrów z ich właściwymi przedstawicielami ${ }^{9}$, a także ustawa z dnia 17 maja 1989 r. o gwarancjach wolności sumienia i wyznania ${ }^{10}$.

Ustawa zasadnicza nie definiuje pojęcia „kościół” ani „związek wyznaniowy”" . Prima facie można uznać, że zwrot „związek wyznaniowy” to pojęcie sensu largo, gdyż każdy „kościół” jest zarazem związkiem wyznaniowym $^{12}$. Pozwala to zatem twierdzić, że „kościół to szczególna nazwa związku wyznaniowego”13. Także według piśmiennictwa termin „kościoły i inne związki wyznaniowe” odnosi się do wszystkich związków religijnych jako podmiotów prawa, o których stanowi art. 25 Konstytucji $\mathrm{RP}^{14}$, „niezależnie od przyjętej nazwy (kościół, zbór, misja, dom, związek itp.)”15.

Obecnie w polskim porządku prawnym istnieje 15 kościołów i związków wyznaniowych mających indywidualnie uregulowane - tzw. ustawami partykularnymi - stosunki z Rzecząpospolitą Polską. Należą do nich wspomniany już Kościół Katolicki oraz Kościół Adwentystów Dnia

7 Wymiana dokumentów ratyfikacyjnych nastąpiła 25 marca, a Konkordat wszedł w życie miesiąc później, tj. 25 kwietnia 1998 roku (Dz.U. z 1998 r., Nr 51, poz. 318), dalej: Konkordat.

8 Tekst jedn. Dz.U. z 2019 r., poz. 1347 ze zm.

9 Zakres podmiotowy art. 25 ust. 5 Konstytucji RP odnosi się do wszystkich - poza Kościołem katolickim - kościołów i związków wyznaniowych i „przewiduje ustawową formę określania stosunków państwa z pozostałymi wspólnotami religijnymi, zarazem wymagając, by podstawą takich ustaw były „umowy” zawierane przez Radę Ministrów z właściwymi przedstawicielami tych wspólnot” - L. Garlicki, Komentarz do art. 25 Konstytucji RP [w:] L. Garlicki, M. Zubik (red.), Konstytucja Rzeczypospolitej Polskiej. Komentarz, tom I, LEX/el. 2016; wyrok NSA z dnia 9 lutego 2016 r., I OSK 579/15, CBOSA.

10 Tekst jedn. Dz.U. z 2017 r., poz. 1153 ze zm., dalej: u.g.w.s.w.

11 B. Banaszak, Komentarz do art. 25 Konstytucja RP [w:] B. Banaszak, Konstytucja Rzeczypospolitej Polskiej. Komentarz, Legalis/el. 2012.

12 L. Garlicki, Komentarz do art. 25 Konstytucji RP..., LEX/el. 2016.

13 B. Banaszak, Komentarz do art. 25 Konstytucja RP..., Legalis/el. 2012.

14 M. Olszówka, Komentarz do art. 25 Konstytucji RP [w:] M. Safjan, L. Bosek (red.), Konstytucja RP. Komentarz do art. 1-86, tom I, Legalis/el. 2016.

15 Tamże. 
Siódmego ${ }^{16}$, Polski Autokefaliczny Kościół Prawosławny ${ }^{17}$, Kościół Chrześcijan Baptystów ${ }^{18}$, Kościół Ewangelicko-Augsburski ${ }^{19}$, Kościół Ewangelicko-Metodystyczny ${ }^{20}$, Kościół Ewangelicko-Reformowany ${ }^{21}$, Kościół Katolicki Mariawitów ${ }^{22}$, Kościół Polskokatolicki ${ }^{23}$, Kościół Starokatolicki Mariawitów ${ }^{24}$, Wschodni Kościół Staroobrzędowy ${ }^{25}$, Kościół Zielonoświątkowy ${ }^{26}$, Karaimski Związek Religijny ${ }^{27}$, Muzułmański Związek Religijny $^{28}$, Związek Gmin Wyznaniowych Żydowskich ${ }^{29}$.

Sytuację prawną kościołów i związków wyznaniowych, nieuregulowaną aktami prawnymi o charakterze partykularnym, normuje ustawa z dnia 17 maja 1989 r. o gwarancjach wolności sumienia i wyznania wraz z przepisami wykonawczymi, a w szczególności rozporządzenie Ministra Spraw Wewnętrznych i Administracji z dnia 31 marca 1999 r. w sprawie

16 Ustawa z dnia 30 czerwca 1995 r. o stosunku Państwa do Kościoła Adwentystów Dnia Siódmego w Rzeczypospolitej Polskiej (tekst jedn. Dz.U. z 2014 r., poz. 1889 ze zm.).

17 Ustawa z dnia 4 lipca 1991 r. o stosunku Państwa do Polskiego Autokefalicznego Kościoła Prawosławnego (tekst jedn. Dz.U. z 2014 r., poz. 1726 ze zm.).

18 Ustawa z dnia 30 czerwca 1995 r. o stosunku Państwa do Kościoła Chrześcijan Baptystów w Rzeczypospolitej Polskiej (tekst jedn. Dz.U. z 2015 r., poz. 169 ze zm.).

19 Ustawa z dnia 13 maja 1994 r. o stosunku Państwa do Kościoła Ewangelicko-Augsburskiego w Rzeczypospolitej Polskiej (tekst jedn. Dz.U. z 2015, poz. 43 ze zm.).

20 Ustawa z dnia 30 czerwca 1995 r. o stosunku Państwa do Kościoła EwangelickoMetodystycznego w Rzeczypospolitej Polskiej (tekst jedn. Dz.U. z 2014 r., poz. 1712 ze zm.).

21 Ustawa z dnia 13 maja 1994 r. o stosunku Państwa do Kościoła EwangelickoReformowanego w Rzeczypospolitej Polskiej (tekst jedn. Dz.U. z 2015 r., poz. 483 ze zm.).

22 Ustawa z dnia 20 lutego 1997 r. o stosunku Państwa do Kościoła Katolickiego Mariawitów w Rzeczypospolitej Polskiej (tekst jedn. Dz.U. z 2015 r., poz. 44 ze zm.)

23 Ustawa z dnia 30 czerwca 1995 r. o stosunku Państwa do Kościoła Polskokatolickiego w Rzeczypospolitej Polskiej (tekst jedn. Dz.U. z 2014 r., poz. 1599 ze zm.).

24 Ustawa z dnia 20 lutego 1997 r. o stosunku Państwa do Kościoła Starokatolickiego Mariawitów w Rzeczypospolitej Polskiej (tekst jedn. Dz.U. z 2015 r., poz. 14 ze zm.).

25 Rozporządzenie Prezydenta Rzeczypospolitej z dnia 22 marca 1928 r. o stosunku Państwa do Wschodniego Kościoła Staroobrzędowego, nie posiadającego hierarchji duchownej (Dz.U. z 1928 r., Nr 38, poz. 363).

26 Ustawa z dnia 20 lutego 1997 r. o stosunku Państwa do Kościoła Zielonoświątkowego w Rzeczypospolitej Polskiej (tekst jedn. Dz.U. z 2015 r., poz. 13 ze zm.).

27 Ustawa z dnia 21 kwietnia 1936 r. o stosunku Państwa do Karaimskiego Związku Religijnego w Rzeczypospolitej Polskiej (Dz.U. z 1936 r., Nr 30, poz. 241).

28 Ustawa z dnia 21 kwietnia 1936 r. o stosunku Państwa do Muzułmańskiego Związku Religijnego w Rzeczypospolitej Polskiej (Dz.U. z 1936 r., Nr 30, poz. 240).

29 Ustawa z dnia 20 lutego 1997 r. o stosunku Państwa do Gmin Wyznaniowych Żydowskich w Rzeczypospolitej Polskiej (tekst jedn. Dz.U. z 2014 r., poz. 1798 ze zm.). 
rejestru kościołów i innych związków wyznaniowych ${ }^{30}$. Dodać należy, że prawo wpisu do wskazanego powyżej rejestru, prowadzonego przez ministra właściwego do spraw wyznań religijnych oraz mniejszości narodowych i etnicznych, jest realizowane poprzez złożenie organowi rejestrowemu deklaracji o utworzeniu kościoła lub innego związku wyznaniowego wraz z wnioskiem o wpis ${ }^{31}$. Na dzień 15 maja 2021 r., według danych z rejestru kościołów i innych związków wyznaniowych, mamy 189 kościołów i innych związków wyznaniowych oraz 5 organizacji międzykościelnych ${ }^{32}$.

Reasumując, przez prawnie uznane wyznania należy rozumieć kościoły i związki wyznaniowe mające indywidualnie uregulowane stosunki z Rzecząpospolitą Polską w ramach tzw. ustaw partykularnych oraz kościoły i związki wyznaniowe działające na mocy ustawy z dnia 17 maja 1989 r. o gwarancjach wolności sumienia i wyznania ${ }^{33}$. Innymi słowy, prawnie uznane wyznania to kościoły i związki wyznaniowe istniejące legalnie ${ }^{34}$.

\section{Status osób duchownych prawnie uznanych wyznań}

Kościoły i związki wyznaniowe, mające uregulowaną sytuację prawną w Polsce, posiadają autonomię w zakresie wykonywania tzw. władzy duchownej $^{35}$, która odnosi się nie tylko do ich działalności religijnej sensu stricto, ale również spraw organizacyjno-samorządowych, np. hierarchii,

\footnotetext{
Dz.U. z 1999 r., Nr 38, poz. 374 ze zm., dalej: rozporządzenie MSWiA.

Art. 30 u.g.w.s.w.

32 https://www.gov.pl/web/mswia/rejestr-kosciolow-i-innych-zwiazkow-wyznaniowych (dostęp: 4.07.2021 r.).

33 P. Pietrasz, Komentarz do art. 195 o.p. [w:] L. Etel (red.), Ordynacja podatkowa. Komentarz aktualizowany, LEX/el. 2021; B. Dauter, Komentarz do art. 195 o.p. [w:] S. Babiarz, B. Dauter, R. Hauser, A. Kabat, M. Niezgódka-Medek, J. Rudowski, Ordynacja podatkowa. Komentarz, LEX/el. 2019.

34 Por. E. Iserzon, Komentarz do art. 73 k.p.a. [w:] E. Iserzon, J. Starościak, Kodeks postępowania administracyjnego. Komentarz. Teksty. Wzory i formularze, Warszawa 1970, s. 173.

35 Wyrok WSA w Warszawie z dnia 6 czerwca 2012 r., II SA/Wa 644/12, CBOSA.
} 
obsady personalnej urzędów sprawujących kult, ale także kwestii przyjmowania i wykluczania wiernych ze wspólnoty, łącznie z ich pozycją w ramach tej struktury ${ }^{36}$.

Brak definicji pojęcia „duchowny/osoba duchowna”37 w ustawodawstwie powszechnie obowiązującym (w tym również podatkowym) wymaga od interpretatora przede wszystkim wnikliwego zapoznania się z prawem wewnętrznym poszczególnych kościołów lub związków wyznaniowych o uregulowanej sytuacji prawnej ${ }^{38}$, uzewnętrznionym co do zasady w ich statucie, określającym w szczególności sposób powoływania, odwoływania oraz kompetencje osób duchownych, o ile oczywiście kościół lub związek wyznaniowy przewiduje tworzenie takich stanowisk ${ }^{39}$.

Próby „odkodowania” pojęcia duchowny prezentowane są także w orzecznictwie, w którym wskazuje się, że jest nim osoba należąca do kościoła lub związku wyznaniowego o uregulowanej sytuacji prawej (w ramach formy ustawowej lub tzw. aktu rejestracji przez ministra), która powołana została z reguły w przepisach wewnętrznych związków religijnych do stałego organizowania i sprawowania kultu religijnego ${ }^{40}$. Jak trafnie zauważa również piśmiennictwo, „osoby duchowne to osoby posiadające szczególny status, wynikający z wewnętrznych - ustalonych

36 Postanowienie SN z dnia 12 maja 2016 r., IV CSK 529/15; W. Brzozowski, Niedopuszczalność sq̨dowej kontroli prawidłowości stosowania przez zwiqzzek wyznaniowy własnego prawa. Glosa do postanowienia SN z dnia 12 maja 2016 r., IV CSK 529/15, „Przegląd Sądowy” 2017, nr 5, s. 117-123.

37 Por. K. Pachnik, Odpowiedzialność karna duchownego przed sq̨dem powszechnym, „Prokurator” 2011, nr 3-4, s. 54.

38 A. Bartosiewicz, R. Kubacki, PIT. Komentarz, LEX/el. 2015.

39 Warto także podnieść, że zgodnie z $\S 5$ ust. 1 rozporządzenia MSWiA wpisowi do informatycznego rejestru podlegają dane i informacje według następującego porządku: informacja o osobach duchownych i zakonnych w myśl prawa państwowego zob. także art. 12 ust. 3 u.g.w.s.w. w związku z art. 32 ust. 2 pkt 9 u.g.w.s.w.; wyrok NSA z dnia 19 września 2000 r., III SA 1411/00, CBOSA; A. Kaźmierski (red.), Meritum Podatki 2020, Warszawa 2020, s. 694.

40 Por. uchwała SN z dnia 6 maja 1992 r., I KZP 1/92, LEX/el.; M. Poniatowski, Zespół praw i obowiq̨zków osoby duchownej jako pokrzywdzonego w postępowaniu karnym zwyczajnym, „Studia z Prawa Wyznaniowego” 2018, tom 21, s. 32; R. Jurowiec, Ewolucja opodatkowania dochodów osób duchownych, „Elpis” 2014, nr 16, s. 217; K. Knoppek, Komentarz do art. 261 k.p.c. [w:] H. Dolecki, T. Wiśniewski (red.), Kodeks postępowania cywilnego. Komentarz (artykuły 1-366), tom I, LEX/el. 2013. 
w dowolnej, wiążącej członków formie - reguł funkcjonowania związku wyznaniowego. Osoby te powinny wykonywać lub być uprawnione do wykonywania takich czynności związanych z kultem religijnym, które, ze względu na wskazane wyżej reguły, nie mogą być wykonywane przez każdego członka wspólnoty" ${ }^{\text {. }}$.

\section{Duchowny jako świadek}

Świadkiem może być tylko i wyłącznie osoba fizyczna ${ }^{42}$, która w procedurze podatkowej dotyczącej praw lub obowiązków innego podmiotu składa zeznania ${ }^{43}$ co do faktów spostrzeżonych przez siebie, jak również tych, o których dowiedziała się od innych osób ${ }^{44}$. Innymi słowy, środek dowodowy z zeznań duchownego może przybrać charakter dowodu bezpośredniego, kiedy osoba ta zeznaje na temat faktu zaobserwowanego przez siebie, lub dowodu pośredniego, gdy świadek zeznaje na temat faktu dostrzeżonego przez inną osobę, która te obserwacje mu przekazała (tzw. świadek ze słyszenia) $^{45}$. Analogiczne rozumienie pojęcia świadka przyjęte jest także w nauce prawa podatkowego oraz w orzecznictwie sądowym, zgodnie z którymi świadek to osoba obecna przy czymś, mogąca stwierdzić to, co widziała, świadczyć o tym, przy czym była ${ }^{46}$. Dodat-

41 A. Huchla, Ustawa o zryczałtowanym podatku dochodowym od niektórych przychodów osiaganych przez osoby fizyczne. Komentarz, LEX/el. 2001.

42 Rozumując a contrario, „Świadkiem nie może być osoba prawna ani też jednostka organizacyjna niemająca osobowości prawnej” - P. Pietrasz, Komentarz do art. 195 o.p..., LEX/el. 2021; por. M. Poniatowski, Zespół..., s. 27. B. Brzeziński, M. Kalinowski, A. Olesińska (red.), Ordynacja podatkowa. Komentarz praktyczny, Gdańsk 2017, s. 965. B. Rutkowski, Dowody w postępowaniu podatkowym, Warszawa 1999, s. 123 i n.; wyrok WSA w Krakowie z dnia 26 lutego 2010 r., II SA/Kr 1811/09, CBOSA.

45 J. Zimmermann, Ordynacja podatkowa. Komentarz. Postępowanie podatkowe, Toruń 1998, s. 179; por. H. Knysiak-Sudyka, Komentarz do art. 82 k.p.a. [w:] H. Knysiak-Sudyka (red.), Kodeks postępowania administracyjnego. Komentarz, LEX/el. 2019; por. Z. Janowicz, Kodeks postępowania administracyjnego. Ustawa o Naczelnym Sqdzie Administracyjnym. Komentarz, LEX/el. 1996; F. Elżanowski, Komentarz do art. 82 k.p.a. [w:] R. Hauser, M. Wierzbowski (red.), Kodeks postępowania administracyjnego. Komentarz, Legalis/el. 2020.

46 I. Nowak, Dowód z zeznań świadka na gruncie jurysdykcyjnego postępowania podatkowego, „Prawo Budżetowe Państwa i Samorządu” 2019, nr 1, s. 129-165; P. Pietrasz, 
kowo podkreślić należy, że przesłuchanie osoby duchownej jako świadka może obejmować nie tylko jego osobiste spostrzeżenia, ale również okoliczności dotyczące samego świadka, jak np. stan jego świadomości czy sposób myślenia ${ }^{47}$.

Czynny podmiot stosunku podatkowoprawnego w inkwizycyjnej procedurze podatkowej - zgodnie z zasadą prawdy obiektywnej wynikającą z art. 122 o.p. w powiązaniu z art. 187 o.p. - podejmuje wszelkie niezbędne działania w celu dokładnego wyjaśnienia stanu faktycznego oraz załatwienia sprawy ${ }^{48}$ m.in. poprzez dobór środków dowodowych oraz ich ocenę ${ }^{49}$. Przy czym, zgodnie z art. 180 § 1 o.p. jako dowód należy dopuścić wszystko, co może przyczynić się do wyjaśnienia sprawy, a nie jest sprzeczne z prawem, pamiętając, że wskazane w art. 181 o.p. rodzaje dowodów należy odczytywać jako ich egzemplifikację, a nie wyczerpujące $_{\text {wyliczenie }}{ }^{50}$. Oznacza to, że na gruncie polskiej procedury podatkowej obowiązuje otwarty system dowodów ${ }^{51}$, gdzie tzw. granice dowodzenia określone w art. 180 § 1 o.p. zostały wyznaczone „przyczynianiem się” danego środka dowodowego do wyjaśnienia sprawy oraz brakiem jego „sprzeczności z prawem”52. Zatem dowód z przesłuchania osoby duchownej należy traktować jako jeden ze środków dowodowych ${ }^{53}$, unormowanych w art. $180 \S 1$ o.p., pamiętając przy tym, że wszystkie środki dowo-

Komentarz do art. 195 o.p..., LEX/el. 2021; wyrok WSA w Warszawie z dnia 17 stycznia 2007 r., III SA/Wa 2702/06, CBOSA; wyrok NSA z dnia 15 grudnia 2010 r., I FSK 95/10, CBOSA; wyrok WSA w Szczecinie z dnia 2 marca 2016 r., I SA/Sz 980/15, CBOSA; wyrok WSA w Szczecinie z dnia 6 kwietnia 2016 r., I SA/Sz 1312/15, CBOSA.

47 Wyrok WSA w Opolu z dnia 20 lipca 2018 r., I SA/Op 81/18, CBOSA.

48 Wyrok WSA w Gliwicach z dnia 27 stycznia 2017 r., III SA/Gl 1074/16, CBOSA.

49 A. Hanusz, Podstawa faktyczna rozstrzygnięcia podatkowego, LEX/el. 2004; wyroki WSA w Warszawie z dnia 23 kwietnia 2015 r., VII SA/Wa 2475-76/14, CBOSA; wyroki NSA z dnia 28 marca 2017 r., II OSK 1928-29/15, CBOSA.

50 Wyroki WSA w Poznaniu z dnia 31 stycznia 2020 r., I SA/Po 762-772/19, CBOSA.

51 Wyrok WSA w Gdańsku z dnia 10 kwietnia 2018 r., I SA/Gd 177/18, CBOSA.

52 I. Nowak, Status biegłego i jego opinii jako dowodu w jurysdykcyjnym postępowaniu podatkowym (cz. I), „Przegląd Podatków Lokalnych i Finansów Samorządowych” 2018, nr 4, s. 23; wyrok WSA w Krakowie z dnia 27 września 2017 r., I SA/Kr 179/17, CBOSA.

53 Wyrok NSA z dnia 18 maja 2018 r., I FSK 1201/16, CBOSA. 
dowe korzystają z jednakowej mocy dowodowej ${ }^{54}$, a ponadto, iż w procesie podatkowym nie obowiązuje formalna teoria dowodowa ${ }^{55}$, według której daną okoliczność można udowodnić wyłącznie przy pomocy takiego, a nie innego środka dowodowego ${ }^{56}$.

\section{Bezwzględny zakaz dowodowy z art. 195 pkt 3 Ordynacji podatkowej}

Duchowni prawnie uznanych wyznań ${ }^{57}$ - zgodnie z regulacją art. 195 pkt 3 o.p. - nie mogą być świadkami co do faktów objętych tajemnicą spowiedzi $^{58}$, co bez wątpienia koresponduje z zasadą ustrojową unormowaną w przepisie art. 53 ust. 1 Konstytucji RP, statuującą konstytucyjną gwarancję wolność sumienia i wolność religii ${ }^{59}$, a tym samym uniemożliwiającą organom administracji publicznej ewentualną ingerencję w zakres spowiedzi na drodze procedury podatkowej, co bez wątpienia wzmacnia zaufanie wiernych względem duchownych ${ }^{60}$. Innymi słowy, z przepisu art. 195 pkt 3 o.p. wynika dla organów podatkowych zakaz przesłuchiwania

54 Za wyjątkiem ksiąg podatkowych (art. 193 o.p.) oraz dokumentów urzędowych (art. 194 o.p.) jako dowodów korzystających ze szczególnych domniemań wzmacniających ich moc dowodową - wyrok WSA w Warszawie z dnia 13 sierpnia 2004 r., III SA 770/03, CBOSA.

55 Szerzej D. Strzelec, Naruszenia przepisów postępowania przez organy podatkowe, Warszawa 2009, s. 184 i n.

56 J. Glumińska-Pawlic, Jeszcze raz na temat dowodów w postępowaniu podatkowym [w:] J. Glumińska-Pawlic (red.), Doradca podatkowy obrońca praw podatnika, tom III, Katowice 2009, s. 19; I. Nowak, Dowód z przesłuchania strony w procedurze podatkowej - uwagi de lege lata $i$ de lege ferenda, „Toruński Rocznik Podatkowy” 2018/el, s. 1-16; wyrok NSA z dnia 29 listopada 2011 r., I OSK 1197/11, CBOSA; wyrok WSA we Wrocławiu z dnia 22 września 2017 r., II SA/Wr 560/16, CBOSA.

57 Według piśmiennictwa określenie „duchowni prawnie uznanych wyznań” jest precyzyjniejsze niż w przepisie art. 82 pkt 3 k.p.a. - W. Chróścielewski, W. Nykiel, Ordynacja podatkowa a przepisy Kodeksu postępowania administracyjnego [w:] B. Brzeziński, C. Kosikowski (red.), Studia nad Ordynacja podatkowq, Łódź-Toruń 1999, s. 50.

58 Por. E. Iserzon, Komentarz do art. 77 k.p.a..., s. 173.

59 M. Florczak-Wątor, Komentarz do art. 53 Konstytucji RP [w:] P. Tuleja (red.), Konstytucja Rzeczypospolitej Polskiej. Komentarz, LEX/el. 2019.

60 Por. P. Hofmański, Komentarz do art. 178 k.p.k. [w:] P. Hofmański, E. Sadzik, K. Zgryzek, Kodeks postępowania karnego. Komentarz do art. 1-296, tom I, Legalis/el. 2011. 
jako świadka duchownego co do faktów ujawnionych mu na spowiedzi (tzw. bezwzględny zakaz dowodowy, który nie może zostać uchylony) ${ }^{61}$.

Podmiotem zakazu wskazanym w art. 195 pkt 3 o.p. jest duchowny kościoła albo związku wyznaniowego, w którym jest uprawniony do spowiadania wiernych ${ }^{62}$ oraz w którym występuje spowiedź indywidualna (tajna, uszna, konfesyjna), jak ma to miejsce np. w Kościele Katolickim, w Polskim Autokefalicznym Kościele Prawosławnym, w Kościele Starokatolickim Mariawitów czy w Kościele Polskokatolickim ${ }^{63}$. Nie ulega zatem wątpliwości, że instytucja spowiedzi musi być uregulowana w przepisach wewnętrznych kościołów i związków wyznaniowych, przewidujących „taką zasadę religijną”64 wraz z osobą duchownego, upoważnionego do jej przyjmowania ${ }^{65}$. Przykładowo, według trafnego poglądu judykatury judaizm nie zawiera żadnej czynności religijnej, która mogłaby być utożsamiana ze spowiedzią ${ }^{66}$.

Instytucję spowiedzi, pomimo że nie posiada definicji legalnej, należy rozumieć jako wyznanie grzechów przed osobą duchowną. W każdym zatem przypadku, kiedy „pomiędzy duchownym a osobą, od której pochodzi informacja, wystąpiła tego rodzaju relacja, że jej cechy odpowiadają cechom spowiedzi rozumianej jako poufne i przewidziane formalnym

61 A. Olesińska, Polskie prawo podatkowe, Toruń 2012, s. 200; B. Brzeziński, M. Kalinowski, M. Masternak, A. Olesińska, J. Orłowski, Ordynacja podatkowa. Komentarz, tom II, Toruń 2007, s. 312; J. Bonarski, Zakazy dowodowe w Ordynacji podatkowej [w:] R. Dowgier (red.), Ordynacja podatkowa. Dowody w postępowaniu podatkowym, Białystok 2013, s. 138; por. B. Pieron, Ochrona tajemnicy spowiedzi w prawie polskim, „Kieleckie Studia Teologiczne” 2012, nr 11, s. 333.

62 Por. T. Grzegorczyk, Komentarz do art. 178 k.p.k. [w:] T. Grzegorczyk, Kodeks postępowania karnego. Komentarz. Artykuły 1-467, tom I, LEX/el. 2014.

63 M. Tomkiewicz, „Tajemnica spowiedzi” i „tajemnica duszpasterska” w procesie karnym, „Prokuratura i Prawo” 2012, nr 2, s. 51 i n.; por. P. Gensikowski, Komentarz do art. 178 k.p.k. [w:] D. Drajewicz (red.), Kodeks postępowania karnego. Komentarz. Art. 1-424, tom I, Legalis/el. 2020.

64 Por. Cz. Martysz, Komentarz do art. 82 k.p.a. [w:] G. Łaszczyca, Cz. Martysz, A. Matan, Kodeks postępowania administracyjnego. Komentarz do art. 1-103, tom I, LEX/el. 2010.

65 Por. wyrok SN z dnia 14 czerwca 1937 r., I K 454/37, LEX/el.

66 Por. wyrok SN z dnia 14 czerwca 1937 r., I K 454/37, LEX/el.; F. Elżanowski, Komentarz do art. 82 k.p.a..., Legalis/el. 2020; tenże, Komentarz do art. 82 k.p.a. [w:] M. Wierzbowski, A. Wiktorowska (red.), Kodeks postępowania administracyjnego. Komentarz, Legalis/el. 2020. 
rytuałem zwierzenie organ administracji podatkowej powinien odstąpić od przeprowadzenia dowodu z zeznań duchownego"67. Co więcej, art. 195 pkt 3 o.p., nie może podlegać wykładni rozszerzającej ${ }^{68}$, np. w ramach tego przepisu organ administracji publicznej nie może żądać od duchownego informacji o osobie, która uczestniczyła w spowiedzi ${ }^{69}$. Wydaje się także, że w sytuacji, kiedy spowiedź nie ma charakteru tajnego, lecz czyniona jest publicznie, obowiązuje również zakaz dowodowy z art. 195 pkt 3 o.p. ${ }^{70}$, ponieważ art. 53 ust. 1 Konstytucji RP gwarantuje każdemu wolność sumienia i wolność religii ${ }^{71}$, niezależnie od tego, o jaką religię chodzi ${ }^{72}$.

Obowiązkiem zachowania tajemnicy spowiedzi zobligowany jest także duchowny, który utracił swój status na rzecz tzw. stanu świeckiego (sekularyzacja, zeświecczenie) ${ }^{73}$ czy też wskutek wygaśnięcia okresu, na jaki został powołany do sprawowania swojej funkcji ${ }^{74}$. Zatem w przypadku osób duchownych - nie tylko czynnych zawodowo - nie dochodzi do zwolnienia ich z obowiązku zachowania tajemnicy spowiedzi ${ }^{75}$ (tzw. brak ograniczenia czasowego), nawet po śmierci osoby spowiadającej się (pe-

67 Por. W. Bochenek, Komentarz do art. 82 k.p.a. [w:] L. Klat-Wertelecka, A. Mudrecki (red.), Kodeks postępowania administracyjnego. Komentarz dla praktyków, Gdańsk 2012, s. 369.

68 Por. wyrok SN z dnia 14 czerwca 1937 r., I K 454/37, LEX/el.; M. Abramek, Duchowny w procesie karnym - rozważania na kanwie zakazu dowodowego z art. 178 pkt 2 KPK, „Monitor Prawniczy” 2019, nr 5, Legalis/el.

69 Por. W. Bochenek, Komentarz do art. 82 k.p.a..., s. 369; M. Tomkiewicz, Ochrona wolności wyznania a stosowanie kontroli operacyjnej w Polsce, „Przegląd Prawa Wyznaniowego" 2017, t. 9, s. 60. Por. Z. Kwiatkowski, Zakazy dowodowe w procesie karnym, LEX/el. 2005; M. Kurowski, Komentarz do art. 178 k.p.k. [w:] D. Świecki (red.), Kodeks postępowania karnego. Komentarz aktualizowany, tom I, LEX/el. 2020.

71 I. Nowak, Wolność..., s. 21-24.

72 Por. P. Hofmański, Komentarz do art. 178 k.p.k..., Legalis/el. 2011.

73 Por. K. Boratyńska, P. Czarnecki, A. Lach, Komentarz do art. 178 k.p.k. [w:] A. Sakowicz (red.), Kodeks postępowania karnego. Komentarz, Legalis/el. 2020.

74 H. Dzwonkowski, J. Gorąca-Paczuska, Komentarz do art. 195 o.p. [w:] H. Dzwonkowski (red.), Ordynacja podatkowa. Komentarz, Legalis/el. 2020; B. Rakoczy, Tajemnica spowiedzi w polskim postępowaniu cywilnym, karnym i administracyjnym, „Przegląd Sądowy” 2003, nr 11-12, s. 126 i n.; por. T. Demendecki, Komentarz do art. 261 k.p.c. [w:] A. Jakubecki (red.), Kodeks postępowania cywilnego. Komentarz aktualizowany. Art. 1-729, tom I, LEX/el. 2019.

75 Por. P. Przybysz, Kodeks postępowania administracyjnego. Komentarz aktualizowany, LEX/el. 2019, (komentarz do art. 82 k.p.a.). 
nitenta) ${ }^{76}$. Nie jest także dopuszczalne na gruncie procedury podatkowej zwolnienie osoby duchownej z tajemnicy spowiedzi w sytuacji, w której sam duchowny lub osoba spowiadająca się na takie przesłuchanie wyraziliby zgodę ${ }^{77}$.

De lege ferenda za uzasadniony należy uznać postulat nowelizacji art. 195 pkt 3 o.p. poprzez rozszerzenie jego zakresu na wszystkie osoby, które w różny sposób weszły w posiadanie wiadomości ze spowiedzi, np. tłumacza, z którego usług skorzystano w trakcie spowiedzi ${ }^{78}$, czy też te osoby, które podsłuchały spowiednika i jego penitenta ${ }^{79}$. W pełni należy także podzielić pogląd - zgłoszony wprawdzie na gruncie procedury karnej - że jeżeli spowiednikiem okazałby się „duchowny nie mający jeszcze stosownych uprawnień, to mimo to należy przyjąć - z uwagi na ratio legis przepisu (art. 195 pkt 3 o.p. - przypis autora) i jego powiązania konstytucyjne - że jego także dotyczy zakaz przesłuchiwania co do okoliczności, o jakich dowiedział się podczas takiej spowiedzi”80. Wydaje się także, że zakaz dowodowy z art. 195 pkt 3 o.p. powinien obowiązywać również spowiednika, który udawał osobę duchowną ${ }^{81}$.

Zakaz dowodowy przewidziany w art. 195 pkt 3 o.p., skierowany expressis verbis do podatkowych organów procesowych, oznacza, że osoby duchowne prawnie uznanych wyznań co do faktów objętych tajemnicą spowiedzi nie mogą być świadkami. Tym samym nie powinni oni być wzywani w takim charakterze ${ }^{82}$, ponieważ duchowny nie ma obowiązku stawiania się na takie wezwanie, gdyż nie wywiera ono żadnych skutków

76 Por. M. Krakowiak, Komentarz do art. 261 k.p.c. [w:] A. Góra-Błaszczykowska (red.), Kodeks postępowania cywilnego. Komentarz. Art. 1-424 ${ }^{12}$, tom I, LEX/el. 2020.

77 Por. R.A. Stefański, S. Zabłocki (red.), Kodeks postępowania karnego. Komentarz do art. 167-296, tom II, LEX/el. 2019.

78 Por. P. Gensikowski, Komentarz do art. 178 k.p.k..., Legalis/el. 2020; M. Tomkiewicz, „Tajemnica spowiedzi”..., s. 57.

79 Por. M. Krakowiak, Komentarz do art. 261 k.p.c..., LEX/el. 2020.

80 T. Grzegorczyk, Komentarz do art. 178 k.p.k..., LEX/el. 2014.

81 B. Rakoczy, Tajemnica..., s. 133; odmiennie A. Biłgorajski, Wolność wypowiedzi versus wolność religijna. Studium z zakresu prawa konstytucyjnego, karnego i cywilnego, Legalis/el. 2015.

82 I. Nowak, Istota i znaczenie wezwań w postępowaniu podatkowym (cz. 1-2), „Przegląd Podatków Lokalnych i Finansów Samorządowych” 2019, nr 7-8, s. 20-26/25-30. 
prawnych $^{83}$. Jeżeli jednak zeznania objęte zakazem z art. 195 pkt 3 o.p. zostaną odebrane od osoby duchownej, to z tzw. przyczyn prawnych ${ }^{84}$ nie mogą być uznane za dowód ${ }^{85}$ - co oznacza, że nie będą kształtować podstawy faktycznej rozstrzygnięcia podatkowego ${ }^{86}$.

\section{Tajemnica duchowna (duszpasterska)}

Duchowni tzw. zalegalizowanych prawnie w Rzeczypospolitej Polskiej wyznań mogą być świadkami w postępowaniu podatkowym z wyłączeniem faktów, o których dowiedzieli się podczas spowiedzi ${ }^{87}$. Innymi słowy, na gruncie art. 195 pkt 3 o.p. oraz innych powszechnie obowiązujących w Rzeczypospolitej aktów prawnych wiadomości uzyskane przez osobę duchowną w ramach tzw. opieki/posługi duchowej, jeśli nie są one połączone ze spowiedzią, nie podlegają ochronie w ramach tajemnicy spowiedzi, analogicznie jak inne wiadomości, o których duchowny dowiedział się w związku z pełnieniem swych obowiązków ${ }^{88}$.

83 I. Nowak, Wezwania w świetle pomocy prawnej pomiędzy organami administracji podatkowej na gruncie art. 157 i 157a Ordynacji podatkowej, „Kwartalnik Prawa Podatkowego” 2018, nr 3, s. 43-68; A. Biłgorajski, Wolność..., Legalis/el. 2015; wyrok WSA w Warszawie z dnia 10 grudnia 2008 r., I SA/Wa 1318/08, CBOSA.

84 Ograniczenia zdolności do wystąpienia w charakterze świadka wypływają również z przyczyn o charakterze faktycznym, np. niezdolności do postrzegania lub komunikowania swych spostrzeżeń (art. 195 pkt 1 o.p.) - B. Adamiak, Komentarz do art. 195 o.p. [w:] B. Adamiak, J. Borkowski, P. Borszowski, R. Mastalski, J. Zubrzycki, Ordynacja podatkowa. Komentarz, Wrocław 2017, s. 1154; wyrok WSA w Gliwicach z dnia 8 listopada 2010 r., III SA/Gl 1000/10, CBOSA.

85 Por. A. Wróbel, Komentarz do art. 82 k.p.a. [w:] M. Jaśkowska, M. Wilbrandt-Gotowicz, A. Wróbel, Komentarz aktualizowany do Kodeksu postępowania administracyjnego, LEX/el. 2020.

86 A. Hanusz, Podstawa..., LEX/el. 2004; por. E. Iserzon, Komentarz do art. 77 k.p.a..., s. 173; D. Gruszecka, Komentarz do art. 178 k.p.k. [w:] J. Skorupka, Kodeks postępowania karnego. Komentarz, Legalis/el. 2020.

87 Por. A. Wróbel, Komentarz do art. 82 k.p.a..., LEX/el. 2020; M. Król, Niemożność bycia świadkiem w postępowaniu administracyjnym przez duchownego katolickiego w świetle Kodeksu postępowania administracyjnego i Kodeksu prawa kanonicznego z 1983 roku, „Acta Iuris Stetinensis” 2018, nr 3, s. 130 i n.

88 Por. K.T. Boratyńska, Komentarz do art. 178 k.p.k. [w:] K.T. Boratyńska, A. Górski, A. Sakowicz, A. Ważny, Kodeks postępowania karnego. Komentarz, Legalis/el. 2009; A. Turczyn, Komentarz do art. 261 k.p.c. [w:] O.M. Piaskowska (red.), Kodeks postępowania cywilnego. Postępowanie procesowe. Komentarz, LEX/el. 2020. 
W świetle powyższych rozważań uzasadniony jest wniosek, że w obszarze art. 195 pkt 3 o.p. konieczna jest „interwencja ustawodawcza” polegająca na wprowadzeniu zakazu dowodowego i objęcie jego zakresem tzw. tajemnicy duchownej/duszpasterskiej, która dotyczyłaby wszystkich wiadomości/informacji uzyskanych przez osoby duchowne prawnie uznanych wyznań od wiernego przy wykonywaniu swoich „funkcji duszpasterskich”89, a nie stricte instytucji spowiedzi ${ }^{90}$. Za wzorcowe pod tym względem należy uznać rozwiązania prawne przyjęte w Ordynacji podatkowej z 1934 r. ${ }^{91}$, jak i w dekrecie o postępowaniu podatkowym z 1946 r., a stanowiące, że: świadkami nie mogą być duchowni prawnie uznanych wyznań co do faktów, powierzonych im na spowiedzi lub pod tajemnicą duchowną $^{92}$. Taki zabieg legislacyjny wyeliminowałby obecną lukę prawną w tym zakresie, którą trudno przecież pogodzić z konstytucyjną zasadą wolności sumienia i wyznania ${ }^{93}$. Na fakt, że pojęcie „tajemnica duchowna/duszpasterska” ma szersze znaczenie niż spowiedź, wskazują także regulacje innych przedwojennych procedur ${ }^{94}$. Przykładowo, zgodnie z art. 59 lit. b) rozporządzenia Prezydenta Rzeczypospolitej z dnia 22 marca 1928 r. o postępowaniu administracyjnym duchowni co do tego, co im powierzono na spowiedzi lub pod tajemnicą duchowną, nie mogą być badani w charakterze świadków ${ }^{95}$. Również według art. 284 pkt 2 Kodeksu postępowania cywilnego z roku 1932 r. świadkami nie mogą być duchowni co do faktów powierzonych im na spowiedzi lub pod tajemnicą duchowną ${ }^{96}$ Analogicznie podnosi M. Tomkiewicz, zauważając,

89 M. Tomkiewicz, „Tajemnica spowiedzi”..., s. 63; P. Gensikowski, Komentarz do art. 178 k.p.k..., Legalis/el. 2020; B. Rakoczy, Tajemnica..., s. 132.

90 Por. M. Strzała, Prawo odmowy zeznań przez duchownego w polskiej i niemieckiej procedurze cywilnej - analiza prawno-porównawcza, „Studia z Prawa Wyznaniowego” 2018, t. 21, s. 176-178.

91 Tekst jedn. Dz.U. z 1936 r., Nr 39, poz. 346 ze zm.

92 Tekst jedn. Dz.U. z 1963, Nr 11, poz. 60 ze zm.

93 Por. H. Knysiak-Sudyka, Komentarz do art. 82 k.p.a..., LEX/el. 2019.

94 Por. M. Szymański, Tajemnica spowiedzi w prawie polskim - stan aktualny i propozycje zmian, „Internetowy Przegląd Prawniczy TBSP UJ” 2017, nr 4, s. 78; M. Tomkiewicz, , Tajemnica spowiedzi”..., s. 62-63.

95 Rozporządzenie Prezydenta Rzeczypospolitej z dnia 22 marca 1928 r. o postępowaniu administracyjnym (Dz.U. z 1928 r., Nr 36, poz. 34 ze zm.). 
że „spowiedź nie jest bowiem jedyną, praktykowaną przez wierzących formą kontaktów o charakterze duchowym. Wierni mogą wszak, niezależnie od spowiedzi, korzystać z rozmów duszpasterskich i porad duchowych, w których stopień poufności i intymności bywa do spowiedzi zbliżony. Tego rodzaju kontakty zajmują szczególne miejsce zwłaszcza w tych Kościołach, które spowiedzi indywidualnej nie przewidują"97, np. w denominacjach protestanckich, które powołując się na autorytet Pisma Świętego (Biblii) jako sui generis „Konstytucji Chrześcijan”98, nie uznają spowiedzi usznej, analogicznie jak celibatu czy też niedzieli jako dnia świętego ${ }^{99}$.

W uzupełnieniu powyższego postulatu należy zaznaczyć, że wprowadzenie instytucjonalnej (ustawowej) „tajemnicy duchownej/duszpasterskiej” do polskiego systemu prawnego na wzór tajemnicy lekarskiej, adwokackiej, radcowskiej, notarialnej itp. - biorąc pod uwagę koncepcję racjonalnego ustawodawcy - byłoby ze wszech miar zasadne ${ }^{100}$. Nawet po „pobieżnej lekturze” rozporządzenia Ministra Pracy i Polityki Społecznej z dnia 7 sierpnia 2014 r. w sprawie klasyfikacji zawodów i specjalności na potrzeby rynku pracy oraz zakresu jej stosowania, wydanego na podstawie art. 36 ust. 8 ustawy z dnia 20 kwietnia 2004 r. o promocji zatrudnienia i instytucjach rynku pracy, uznać należy, że ustawodawca expressis verbis wskazuje duchownych i osoby konsekrowane jako zawody, poprzez ich egzemplifikację na: duchownych religii mojżeszowej, religii muzułmańskiej, wyznania prawosławnego, wyznania rzymskokatolickiego, wyznania ewangelickiego, zakonników (bez święceń kapłańskich) oraz tzw. pozostałych duchownych i osoby konsekrowane, co niepodważalnie świadczy o otwartym katalogu powyższych profesji. Należy jednoznacznie odnotować - o zgrozo - że w aktualnym stanie prawnym brak ochrony

97 M. Tomkiewicz, „Tajemnica spowiedzi”..., s. 60.

98 Por. I. Nowak, Małżeństwo a zwiq̨zki partnerskie w świetle wybranych regulacji polskiego prawa podatkowego, „Kwartalnik Prawa Podatkowego” 2017, nr 3, s. 59.

99 Por. G. Maroń, O klaryfikacyjnych i perswazyjnych funkcjach odwołań do przekazu Ewangelii w piśmiennictwie polskiej nauki prawa, „Prawo i Więź” 2020, nr 3, s. 263.

100 Por. B. Pieron, Tajemnica zawodowa (duszpasterska) duchownego, „Annales Canonici” 2016, nr 12, s. 148; s. 116; P. Kroczek, K. Michałowska, O celowości wprowadzenia tajemnicy duszpasterskiej do prawa polskiego na przykładzie kapelanów szpitalnych, „Kwartalnik Krajowej Rady Sądownictwa” 2018, nr 3-4, s. 116. 
„tajemnicy duchownej/duszpasterskiej” w przepisach regulujących kontrolę operacyjną (m.in. w ramach czynności operacyjno-rozpoznawczych dokonywanych przez funkcjonariuszy Krajowej Administracji Skarbowej - przypis autora ${ }^{101}$ ) ,jest o tyle trudny do zaakceptowania, że w tej samej kontroli operacyjnej inne rodzaje tajemnic zawodowych, jak chociażby tajemnica adwokacka, lekarska, dziennikarska itd., z takiej ochrony korzystają"102.

\section{Podsumowanie}

W Konstytucji RP ustawodawca uregulował status prawny wspólnot religijnych w sposób szczególny, ustanawiając indywidualny katalog gwarancji ich praw ${ }^{103}$, np. konstytucyjny rozdział pomiędzy Państwem a kościołami i związkami wyznaniowymi zabraniający ingerencji organów władzy publicznej w kwestie wewnętrznych relacji danego kościoła z jego wyznawcami $^{104}$. Z tego m.in. powodu duchowni prawnie uznanych wyznań w Polsce na mocy przepisu art. 195 pkt 3 o.p. w postępowaniu podatkowym co do faktów objętych tajemnicą spowiedzi nie mogą być świadkami, gdyż spowiedź jest objęta bezwzględną tajemnicą i dotyczy swym zakresem wszelkich informacji uzyskanych w jej trakcie ${ }^{105}$.

101 Zob. I. Nowak, Funkcjonariusze celni w strukturze Krajowej Administracji Skarbowej - uwagi wybrane, „Kwartalnik Prawa Podatkowego” 2019, nr 2, s. 37-56; tenże National Revenue Administration - current organisational and financial problems, „Prawo Budżetowe Państwa i Samorządu” 2020, nr 2, s. 37-65.

102 M. Tomkiewicz, Ochrona wolności wyznania a stosowanie kontroli operacyjnej w Polsce, „Przegląd Prawa Wyznaniowego” 2017, t. 9, s. 69-70; D. Szubielska, Tajemnica zawodowa w prawie i postępowaniu podatkowym, „Palestra” 2019, nr 7-8, s. 202 i n.

103 Wyrok TK z dnia 2 kwietnia 2003 r., K 13/02, LEX/el.; I. Nowak, Prawo do zwolnienia od pracy z tytułu świq̨t religijnych, „Humanities and Social Sciences” 2015, nr 1, s. 121139; tenże Prawo do nauki a święta religijne mniejszości wyznaniowych na gruncie ustawy o systemie oświaty, „Przegląd Prawa Publicznego” 2014, nr 5, s. 41-54.

104 I. Nowak, Indywidualny rozkład czasu pracy według Kodeksu pracy oraz ustaw z zakresu prawa wyznaniowego [w:] R. Frey (red.), Świadczenie pracy jako przedmiot zobowiq̨zania umownego, cz. II, Kielce 2014, s. 145-161; wyrok WSA w Warszawie z dnia 20 marca 2012 r., II SA/Wa 2493/11, CBOSA.

105 Por. Cz. Martysz, Komentarz do art. 82 k.p.a..., LEX/el. 2010; J. Borkowski, Komentarz do art. 82 k.p.a. [w:] J. Borkowski (red.) Kodeks postępowania administracyjnego. Komentarz, Warszawa 1985, s. 163. 
Zeznania złożone przez osoby duchowne prawnie uznanych wyznań co do faktów objętych tajemnicą spowiedzi nie mogą stanowić dowodu w procedurze podatkowej jako sprzeczne $\mathrm{z}$ prawem ${ }^{106}$. W przeciwnym razie skutkować będą wadliwością prowadzonego procesu podatkowego i oczywiście w jego następstwie rozstrzygnięcie podatkowe musi być usunięte z obrotu prawnego, niezależnie od jego etapu ${ }^{107}$. Jednakże zakaz dowodowy z art. 195 pkt 3 o.p. ma „kierunkowy i ograniczony charakter, albowiem (...) nie ma przeszkody, aby przesłuchać duchownego na okoliczność faktów (...), o których dowiedział się od innych osób czy też w inny sposób niż w trakcie spowiedzi, np. wykonując inne poza duszpasterskimi czynności" ${ }^{\text {108 }}$. Dlatego też, dokonując analizy art. 195 pkt 3 o.p., nie sposób powstrzymać się od krytyki „niedociągnięcia ustawodawcy” w tym przepisie, polegającego na tym, że zakaz dowodowy nie został rozciągnięty na tzw. tajemnicę duchowną/duszpasterską, która powinna wzorem przedwojennego ustawodawstwa (także podatkowego) dotyczyć wszystkich wiadomości/informacji uzyskanych przez osoby duchowne prawnie uznanych wyznań przy wykonywaniu swoich funkcji, a nie tylko związanych z instytucją spowiedzi, ponieważ realizacja tego obowiązku jest zagwarantowana w art. 53 Konstytucji RP ${ }^{109}$.

106 Zob. art. 180 § 1 o.p.; szerzej D. Strzelec, Dowody sprzeczne z prawem w postępowaniu podatkowym, „Przegląd Podatkowy” 2009, nr 1; tenże s. Gwarancje procesowe w postępowaniu podatkowym, „Przegląd Prawa Publicznego” 2011, nr 2, s. 60; T. Woźny, Glosa do wyroku NSA z dnia 26 kwietnia 2000 r., V SA 2162/99, LEX/el. 2008.

107 Por. F. Elżanowski, Komentarz do art. 82 K.p.a..., Legalis/el. 2020; tenże, Komentarz do art. 82 k.p.a. [w:] M. Wierzbowski, A. Wiktorowska (red.), Kodeks..., Legalis/el. 2020; R.A. Stefański, Komentarz do art. 178 k.p.k. [w:] J. Bratoszewski, L. Gardocki, Z. Gostyński, S.M. Przyjemski S. Zabłocki, Kodeks postępowania karnego. Komentarz, tom I, LEX/el. 1998; M. Wielec, Naruszenie zakazu dowodowego tajemnicy spowiedzi w prawie karnym, „Przegląd Prawa Wyznaniowego” 2012, tom 4, s. 122-123; tenże Zakaz dowodowy tajemnicy spowiedzi w postępowaniu karnym, Warszawa 2012, s. 223 i n.

108 D. Strzelec, Dowody i postępowanie dowodowe w prawie podatkowym, LEX/el. 2015.

109 Szerzej M. Safjan, Wyzwania dla państwa prawa, LEX/el. 2007; por. T. Grzegorczyk, Dowody [w:] T. Grzegorczyk, J. Tylman, Polskie postępowanie karne, Warszawa 2011, s. 477. 
Duchowni prawnie uznanych wyznań...

\section{Bibliografia:}

Abramek M., Duchowny w procesie karnym - rozważania na kanwie zakazu dowodowego z art. 178 pkt 2 KPK, „Monitor Prawniczy” 2019, nr 5, Legalis/el.

Adamiak B., Komentarz do art. 195 o.p. [w:] B. Adamiak, J. Borkowski, P. Borszowski, R. Mastalski, J. Zubrzycki, Ordynacja podatkowa. Komentarz, Unimex, Wrocław 2017.

Babiarz S., Bogucki S., Dumas A., Pęk R., Presnarowicz S., Pustuł J., Ryczałty w prawie podatkowym, LEX/el. 2012.

Banaszak B., Komentarz do art. 25 Konstytucja RP [w:] B. Banaszak, Konstytucja Rzeczypospolitej Polskiej. Komentarz, Legalis/el. 2012.

Bartosiewicz A., Kubacki R., PIT. Komentarz, LEX/el. 2015.

Biłgorajski A., Wolność wypowiedzi versus wolność religijna. Studium z zakresu prawa konstytucyjnego, karnego i cywilnego, Legalis/el. 2015.

Bochenek W., Komentarz do art. 82 k.p.a. [w:] L. Klat-Wertelecka, A. Mudrecki (red.), Kodeks postępowania administracyjnego. Komentarz dla praktyków, ODDK, Gdańsk 2012.

Bonarski J., Zakazy dowodowe w Ordynacji podatkowej [w:] R. Dowgier (red.), Ordynacja podatkowa. Dowody w postępowaniu podatkowym, Temida 2, Białystok 2013.

Boratyńska K.T., Komentarz do art. 178 k.p.k. [w:] K.T. Boratyńska, A. Górski, A. Sakowicz, A. Ważny, Kodeks postępowania karnego. Komentarz, Legalis/el. 2009.

Boratyńska K., Czarnecki P., Lach A., Komentarz do art. 178 k.p.k. [w:] A. Sakowicz (red.), Kodeks postępowania karnego. Komentarz, Legalis/el. 2020.

Borkowski J., Komentarz do art. 82 k.p.a. [w:] J. Borkowski (red.) Kodeks postępowania administracyjnego. Komentarz, WP, Warszawa 1985.

Borszowski P., Ustawa o zryczałtowanym podatku dochodowym od niektórych przychodów osiaganych przez osoby fizyczne. Komentarz, LEX/el. 2012.

Brzeziński B., Kalinowski M., Masternak M., Olesińska A., Orłowski J., Ordynacja podatkowa. Komentarz, tom II, TNOiK, Toruń 2007.

Brzeziński B., Kalinowski M., Olesińska A. (red.), Ordynacja podatkowa. Komentarz praktyczny, ODDK, Gdańsk 2017.

Brzozowski W., Niedopuszczalność sqdowej kontroli prawidłowości stosowania przez zwiq̨zek wyznaniowy własnego prawa. Glosa do postanowienia SN z dnia 12 maja 2016 r., IV CSK 529/15, „Przegląd Sądowy” 2017, nr 5, s. 117-123. 
Chróścielewski W., Nykiel W., Ordynacja podatkowa a przepisy Kodeksu postępowania administracyjnego [w:] B. Brzeziński, C. Kosikowski (red.), Studia nad Ordynacja podatkowq, TNOiK, Łódź-Toruń 1999.

Dańczak P., Inni uczestnicy postępowania administracyjnego [w:] W. Chróścielewski (red.), Zakres przedmiotowy i podmiotowy postępowania administracyjnego ogólnego, tom II, część 1, [w serii:] G. Łaszczyca, A. Matan (red.), System Prawa Administracyjnego Procesowego, Wolters Kluwer, Warszawa 2018.

Dauter B., Komentarz do art. 195 o.p. [w:] S. Babiarz, B. Dauter, R. Hauser, A. Kabat, M. Niezgódka-Medek, J. Rudowski, Ordynacja podatkowa. Komentarz, LEX/el. 2019.

Demendecki T., Komentarz do art. 261 k.p.c. [w:] A. Jakubecki (red.), Kodeks postępowania cywilnego. Komentarz aktualizowany. Art. 1-729, tom I, LEX/el. 2019.

Dzwonkowski H., Gorąca-Paczuska J., Komentarz do art. 195 o.p. [w:] H. Dzwonkowski (red.), Ordynacja podatkowa. Komentarz, Legalis/el. 2020.

Elżanowski F., Komentarz do art. 82 k.p.a. [w:] R. Hauser, M. Wierzbowski (red.), Kodeks postępowania administracyjnego. Komentarz, Legalis/el. 2020.

Elżanowski F., Komentarz do art. 82 k.p.a. [w:] M. Wierzbowski, A. Wiktorowska (red.), Kodeks postępowania administracyjnego. Komentarz, Legalis/el. 2020.

Florczak-Wątor M., Komentarz do art. 53 Konstytucji RP [w:] P. Tuleja (red.), Konstytucja Rzeczypospolitej Polskiej. Komentarz, LEX/el. 2019.

Garlicki L., Komentarz do art. 25 Konstytucji RP [w:] L. Garlicki, M. Zubik (red.), Konstytucja Rzeczypospolitej Polskiej. Komentarz, tom I, LEX/el. 2016.

Gensikowski P., Komentarz do art. 178 k.p.k. [w:] D. Drajewicz (red.), Kodeks postępowania karnego. Komentarz. Art. 1-424, tom I, Legalis/el. 2020.

Glumińska-Pawlic J., Jeszcze raz na temat dowodów w postępowaniu podatkowym [w:] J. Glumińska-Pawlic (red.), Doradca podatkowy obrońcq praw podatnika, tom III, ŚOKIDP, Katowice 2009.

Gruszecka D., Komentarz do art. 178 k.p.k. [w:] J. Skorupka, Kodeks postępowania karnego. Komentarz, Legalis/el. 2020.

Grzegorczyk T., Dowody [w:] T. Grzegorczyk, J. Tylman, Polskie postępowanie karne, LexisNexis, Warszawa 2011.

Grzegorczyk T., Komentarz do art. 178 k.p.k. [w:] T. Grzegorczyk, Kodeks postępowania karnego. Komentarz. Artykuły 1-467, tom I, LEX/el. 2014. 
Hanusz A., Podstawa faktyczna rozstrzygnięcia podatkowego, LEX/el. 2004.

Hofmański P., Komentarz do art. 178 k.p.k. [w:] P. Hofmański, E. Sadzik, K. Zgryzek, Kodeks postępowania karnego. Komentarz do art. 1-296, tom I, Legalis/el. 2011.

Huchla A., Ustawa o zryczałtowanym podatku dochodowym od niektórych przychodów osiaganych przez osoby fizyczne. Komentarz, LEX/el. 2001.

Iserzon E., Komentarz do art. 73 k.p.a. [w:] E. Iserzon, J. Starościak, Kodeks postępowania administracyjnego. Komentarz. Teksty. Wzory i formularze, WP, Warszawa 1970.

Iserzon E., Komentarz do art. 77 k.p.a. [w:] E. Iserzon, J. Starościak, Kodeks postępowania administracyjnego. Komentarz. Teksty. Wzory i formularze, WP, Warszawa 1970.

Janowicz Z., Kodeks postępowania administracyjnego. Ustawa o Naczelnym Sqdzie Administracyjnym. Komentarz, LEX/el. 1996.

Jurowiec R., Ewolucja opodatkowania dochodów osób duchownych, „Elpis” 2014, nr 16, s. 215-220.

Jurzyk M., Ochrona spowiedzi w postępowaniu dowodowym a prawa penitenta i duchownego, „Radca Prawny” 2004, s. 67-81.

Kaźmierski A. (red.), Meritum Podatki 2020, Wolters Kluwer, Warszawa 2020.

Knoppek K., Komentarz do art. 261 k.p.c. [w:] H. Dolecki, T. Wiśniewski (red.), Kodeks postępowania cywilnego. Komentarz (artykuły 1-366), tom I, LEX/el. 2013.

Knysiak-Sudyka H., Komentarz do art. 82 k.p.a. [w:] H. Knysiak-Sudyka (red.), Kodeks postępowania administracyjnego. Komentarz, LEX/el. 2019.

Krakowiak M., Komentarz do art. 261 k.p.c. [w:] A. Góra-Błaszczykowska (red.), Kodeks postępowania cywilnego. Komentarz. Art. 1-424², tom I, LEX/el. 2020.

Kroczek P., Michałowska K., O celowości wprowadzenia tajemnicy duszpasterskiej do prawa polskiego na przykładzie kapelanów szpitalnych, „Kwartalnik Krajowej Rady Sądownictwa” 2018, nr 3-4, s. 102-118.

Król M., Niemożność bycia świadkiem w postępowaniu administracyjnym przez duchownego katolickiego w świetle Kodeksu postępowania administracyjnego i Kodeksu prawa kanonicznego z 1983 roku, „Acta Iuris Stetinensis” 2018, nr 3, s. 129-142.

Kurowski M., Komentarz do art. 178 k.p.k. [w:] D. Świecki (red.), Kodeks postępowania karnego. Komentarz aktualizowany, tom I, LEX/el. 2020.

Kwiatkowski Z., Zakazy dowodowe w procesie karnym, LEX/el. 2005. 
Maroń G., O klaryfikacyjnych i perswazyjnych funkcjach odwołań do przekazu Ewangelii w piśmiennictwie polskiej nauki prawa, „Prawo i Więź” 2020, nr 3, s. 236-277.

Martysz Cz., Komentarz do art. 82 k.p.a. [w:] G. Łaszczyca, Cz. Martysz, A. Matan, Kodeks postępowania administracyjnego. Komentarz do art. 1103, tom I, LEX/el. 2010.

Nowak I., Wolność jednostki w zakresie przekonań religijnych i światopoglądowych a zwolnienie od pracy i nauki z tytułu święta religijnego - soboty (szabatu, szabasu), „Przegląd Prawa Publicznego” 2013, nr 1, s. 19-36.

Nowak I., Indywidualny rozkład czasu pracy według Kodeksu pracy oraz ustaw z zakresu prawa wyznaniowego [w:] R. Frey (red.), Świadczenie pracy jako przedmiot zobowiqzania umownego, cz. II, Panzet, Kielce 2014.

Nowak I., Prawo do nauki a święta religijne mniejszości wyznaniowych na gruncie ustawy o systemie oświaty, „Przegląd Prawa Publicznego” 2014, nr 5, s. 41-54.

Nowak I., Prawo do zwolnienia od pracy z tytułu świq̨t religijnych, „Humanities and Social Sciences” 2015, nr 1, s. 121-139.

Nowak I., Małżeństwo a zwiq̨zki partnerskie w świetle wybranych regulacji polskiego prawa podatkowego, „Kwartalnik Prawa Podatkowego” 2017, nr 3, s. 55-83.

Nowak I., Dowód z przesłuchania strony w procedurze podatkowej - uwagi de lege lata i de lege ferenda, „Toruński Rocznik Podatkowy” 2018/el, s. 1-16.

Nowak I., Wezwania w świetle pomocy prawnej pomiędzy organami administracji podatkowej na gruncie art. 157 i 157a Ordynacji podatkowej, „Kwartalnik Prawa Podatkowego" 2018, nr 3, s. 43-68.

Nowak I., Status biegłego i jego opinii jako dowodu w jurysdykcyjnym postępowaniu podatkowym (cz. I), „Przegląd Podatków Lokalnych i Finansów Samorządowych” 2018, nr 4, s. 19-26.

Nowak I., Dowód z zeznań świadka na gruncie jurysdykcyjnego postępowania podatkowego, „Prawo Budżetowe Państwa i Samorządu” 2019, nr 1, s. 129 165, DOI: http://dx.doi.org/10.12775/PBPS.2019.007.

Nowak I., Funkcjonariusze celni w strukturze Krajowej Administracji Skarbowej - uwagi wybrane, „Kwartalnik Prawa Podatkowego” 2019, nr 2, 37-56.

Nowak I., Istota i znaczenie wezwań w postępowaniu podatkowym (cz. 1-2), „Przegląd Podatków Lokalnych i Finansów Samorządowych” 2019, nr 7-8, s. 20-26/25-30.

Nowak I. National Revenue Administration - current organisational and financial problems, „Prawo Budżetowe Państwa i Samorządu” 2020, nr 2, s. 37 65, DOI: http://dx.doi.org/10.12775/PBPS.2020.010. 
Olesińska A., Polskie prawo podatkowe, TNOiK, Toruń 2012.

Olszówka M., Komentarz do art. 25 Konstytucji RP [w:] M. Safjan, L. Bosek (red.), Konstytucja RP. Komentarz do art. 1-86, tom I, Legalis/el. 2016.

Pachnik K., Odpowiedzialność karna duchownego przed sq̨dem powszechnym, „Prokurator” 2011, nr 3-4, s. 52 -59.

Pieron B., Ochrona tajemnicy spowiedzi w prawie polskim, „Kieleckie Studia Teologiczne” 2012, nr 11, s. 321-334.

Pieron B., Tajemnica zawodowa (duszpasterska) duchownego, „Annales Canonici” 2016, nr 12, s. 131-153.

Pieron B., Równe czy identyczne traktowanie osób duchownych w prawie polskim? „Annales Canonici” 2017, nr 13, s. 155-181.

Pietrasz P., Komentarz do art. 195 o.p. [w:] Etel L. (red.), Ordynacja podatkowa. Komentarz aktualizowany, LEX/el. 2021.

Poniatowski M., Zespół praw i obowiq̨zów osoby duchownej jako pokrzywdzonego w postępowaniu karnym zwyczajnym, „Studia z Prawa Wyznaniowego" 2018, tom 21, s. 27-49.

Przybysz P., Kodeks postępowania administracyjnego. Komentarz aktualizowany, LEX/el. 2019, (komentarz do art. 82 k.p.a.).

Rakoczy B., Tajemnica spowiedzi w polskim postępowaniu cywilnym, karnym i administracyjnym, „Przegląd Sądowy” 2003, nr 11--12, s. 126-138.

Rozkrut D. (red.), Mały Rocznik Statystyczny Polski, ZWS, Warszawa 2020.

Rutkowski B., Dowody w postępowaniu podatkowym, ABC, Warszawa 1999.

Safjan M., Wyzwania dla państwa prawa, LEX/el. 2007.

Stefański R.A., Komentarz do art. 178 k.p.k. [w:] J. Bratoszewski, L. Gardocki, Z. Gostyński, S.M. Przyjemski, S. Zabłocki, Kodeks postępowania karnego. Komentarz, tom I, LEX/el. 1998.

Stefański R.A., Zabłocki S. (red.), Kodeks postępowania karnego. Komentarz do art. 167-296, tom II, LEX/el. 2019.

Strzała M., Prawo odmowy zeznań przez duchownego w polskiej i niemieckiej procedurze cywilnej - analiza prawno-porównawcza, „Studia z Prawa Wyznaniowego" 2018, tom 21, s. 158-181.

Strzelec D., Dowody sprzeczne z prawem w postępowaniu podatkowym, „Przegląd Podatkowy” 2009, nr 1, s. 42-49.

Strzelec D., Naruszenia przepisów postępowania przez organy podatkowe, Wolters Kluwer, Warszawa 2009.

Strzelec D., Gwarancje procesowe w postępowaniu podatkowym, „Przegląd Prawa Publicznego” 2011, nr 2, s. 50-61. 
Strzelec D., Dowody i postępowanie dowodowe w prawie podatkowym, LEX/el. 2015.

Szubielska D., Tajemnica zawodowa $w$ prawie i postępowaniu podatkowym, „Palestra” 2019, nr 7-8, s. 202-211.

Szymański M., Tajemnica spowiedzi w prawie polskim - stan aktualny i propozycje zmian, „Internetowy Przegląd Prawniczy TBSP UJ” 2017, nr 4, s. 73-85.

Tomkiewicz M., „Tajemnica spowiedzi” i „tajemnica duszpasterska” w procesie karnym, „Prokuratura i Prawo” 2012, nr 2, s. 50-64.

Tomkiewicz M., Ochrona wolności wyznania a stosowanie kontroli operacyjnej w Polsce, „Przegląd Prawa Wyznaniowego” 2017, t. 9, s. 59-73.

Turczyn A., Komentarz do art. 261 k.p.c. [w:] O.M. Piaskowska (red.), Kodeks postępowania cywilnego. Postępowanie procesowe. Komentarz, LEX/el. 2020.

Wielec M., Zakaz dowodowy tajemnicy spowiedzi w postępowaniu karnym, UKSW, Warszawa 2012.

Wielec M., Naruszenie zakazu dowodowego tajemnicy spowiedzi w prawie karnym, „Przegląd Prawa Wyznaniowego” 2012, tom 4, s. 111-123.

Woźny T., Glosa do wyroku NSA z dnia 26 kwietnia 2000 r., V SA 2162/99, LEX/el. 2008.

Wróbel A., Komentarz do art. 82 k.p.a. [w:] M. Jaśkowska, M. Wilbrandt-Gotowicz, A. Wróbel, Komentarz aktualizowany do Kodeksu postępowania administracyjnego, LEX/el. 2020.

Zimmermann J., Ordynacja podatkowa. Komentarz. Postępowanie podatkowe, TNOiK, Toruń 1998. 